nearly as possible self-supporting. These are described as strongly Christian in intent and influence, proclaiming the dignity of labour and the fundamental importance of training in heart and hand as well as head. Yale's bursary employment scheme, providing employment for more than four hundred of the residents in its new undergraduate hostels, is described in some detail. It is so popular that wellto-do students have applied for bursary work without stipend because of the opportunities it offers for personal development. Harvard also has lately introduced an employment scheme in connexion with its new dormitories. The report emphasizes the increasing recognition of the value of money-earning labour as a part of education, especially its contribution to character-building, and the advantages of co-operative living arrangements.

\section{The Temporary Ley}

THE Welsh Plant Breeding Station, Aberystwyth, has just issued a bulletin entitled "The Temporary Ley", price $7 s .6 d$. It is divided into four sections. The first compares the results obtained with station. bred and commercial grasses when used in simple mixtures. Although in the first year the commercial seeds gave the best yields, distinct advantages were shown by the station-bred varieties in the third year. Relative aggressiveness of the different species in a mixture is also an important point; timothy, for example, failing to become established when sown in conjunction with cocksfoot or perennial rye grass. Section 2 deals with the yield and persistency of different strains of grass and clover. Mixtures containing indigenous species gave both higher yields and better response to phosphatic manuring than those in which such species were in the minority or lacking. Pasture management and its effect on the sward is the subject of the third section. Swards differing widely in botanical composition were subjected to various systems of management, and it was found that the importance of a species is determined by the individual reaction of the plant to the type of management, as well as its ability to withstand competition from other components of the sward under those conditions. The final section consists of an article by Sir R. George Stapledon, director of the Station, on the establishment and maintenance of temporary leys. This will perhaps be of particular value to the agriculturist as it deals largely with the practical aspect of the question. Final emphasis is laid on the fact that success depends on the combination of a well thought-out seeds mixture with good management.

\section{A Pioneer Garden Journalist}

A shore chapter of garden history in the early eighteenth century is unfolded by Mr. W. Roberts, in a paper on Richard Bradley, F.R.S. $(J$. Roy. Hort. Soc., 64, Pt. 4 ; April 1939). Bradley was the first professor of botany at Cambridge, and though he does not appear to have conferred much sound teaching upon his students, nor given academic dignity to the University, he was responsible for a series of volumes which exerted considerable influence upon horticulture at that period. "A General Treatise of Husbandry and Gardening" was one of his greatest contributions, and forms the main subject of $\mathbf{M r}$. Roberts's paper. The text introduces "Such Observations and Experiments as are New and Useful for the Improvement of Land", and, indeed, Bradley's experiments represented his major contribution to horticulture, at a period when it was the fashion only to copy and quote. He states that his expenses in the study of the nature of plants and soils cost him upwards of $£ 2,000$, and he also travelled widely. Though his undertaking to establish a Botanical Garden at Cambridge did not flourish greatly, he distributed much garden knowledge of an exact order.

\section{Earthing with Driven Copper Electrodes}

A HUNDRED years ago, when electricity was usually generated by the use of frictional or Wimshurst machines and detected by gold leaf electroscopes, it was well known that an electric charge on a conducting surface could be dissipated by connecting the charged surface to earth. It is now found that owing to the increasing electric power behind modern networks, in order to get safe operation special attention has to be paid to the conductor connecting charged metallic objects to earth. Copper electrodes of small diameter cannot be driven with a sledge-hammer unless the ground be soft, as the rod will bend or the top will be deformed. The Copper Development Association of Thames House, Milbank, London, S.W.I, has published a booklet entitled "Copper for Earthing" which gives several useful hints on this problem. The most satisfactory method of driving copper electrodes into the earth is by means of an electric hammer which delivers a large number of light blows. The usual procedure is to choose the wettest or the most low-lying spot in the neighbourhood and drive a copper rod of small diameter into the earth to a depth of about eight feet. The earth resistance is then measured; if too high, several more rods can be driven in and connected in parallel. This is necessary for earthing mains where a possible fault current may be very large. The booklet points out that, even now, earth connexions are sometimes made by a few feet of conduit buried outside the house or under the floor in contact with a small iron plate or with the hot-water piping system. Sometimes even a large electric machine is earthed by binding the wire round a loose rock lying on the ground. In one case the earthing wire was found to terminate in a bottle of water !

\section{London's Water in 1937}

THE results of the chemical and bacteriological examination of the London waters for the twelve months ended December 31, 1937, are contained in the thirty-second annual report of the Metropolitan Water Board, recently issued (P. S. King and Son, Ltd., 14 Great Smith Street, Westminster. 10s, 6d.). Much of the report was drafted by the late director, Col. Harold, before his death last July, and the task 